\title{
Development of form and function in the teleost auditory system
}

\author{
DENNIS HIGGS \\ Department of Biology, University of Maryland, College Park MD 20740 USA (dh201@umail.umd.edu)
}

\begin{abstract}
SUMMARY: While much is known about form and function in the adult fish ear, there is little information available $\varepsilon$ to how auditory function changes developmentally in fish. This paper briefly reviews what is known about the development of form and function of the teleost ear and discusses the importance this may have to both the aquaculture setting and to fisheries managers.
\end{abstract}

\section{KEY WORDS: survival, hearing, ear, fish, survival, aquaculture noise, sensory systems}

\section{INTRODUCTION}

For optimal survival in the natural environment, fish need the full functionality of all their sensory systems. Loss of even one system in adult fish can have important implications on the ability to find and capture prey (e.g. $\left.{ }^{1}\right)$ and to escape predators $\left(\right.$ e.g. $\left.{ }^{2}\right)$. While few adult fish are without the use of a sensory system in nature, except when entering a light-limited environment, this is not the case for larval fish. Many species of teleost fish hatch in a very undeveloped state with rudimentary or non-functioning sensory systems ${ }^{3}$. While these systems are developing and becoming functional, larvae must still find food, avoid predators, and find suitable nursery habitats.

The functional and morphological development of the visual and mechanosensory systems of teleosts have been extensively reviewed elsewhere ${ }^{3,4,5,6}$. There has been much less attention devoted to the development of the teleost auditory system however. Audition is used in adult fish for communication (reviewed in ${ }^{7}$ ) and predator detection ${ }^{8}$ and audition may also be an important cue for settlement of larval fish onto coral reefs ${ }^{9}$.

\section{MORPHOLOGY OF THE ADULT FISH EAR}

While there is extensive variation in the fine structure of the teleost ear in adults (reviewed in $\left.{ }^{10}\right)$, there are some general themes that are common throughout this group. Teleosts have three semicircular canals which provide vestibular information, and three otolithic end organs (the saccule, utricle and lagena) that provide a mix of vestibular and auditory information ${ }^{10}$. Each end organ contains a calcareous otolith resting next to a sensory epithelium. The epithelium consists primarily of hair cells (the sensory receptors) and supporting cells. Movements of stereocilia and kinocilia at the tips of the hair cells as a consequence of sound stimulation result in conversion of mechanical to electrical signals and thus are the first step in the process of hearing. While sound localization and directional hearing are difficult issues to study in fish, there is evidence that fish can determine at least the direction from which sounds arrive (e.g. $\left.{ }^{11}\right)$. It is thought that this feat is accomplished partially through the polarity of the stereocilia and kinocilia arrangement ${ }^{\text {To }}$. If stereocilia are bent toward the kinocilium in response to a sound wave, the hair cell is maximally stimulated but if stereocilia are bent away from the kinocilium, the hair cell is inhibited ${ }^{10}$. By integrating patterns of auditory hair cell stimulation across the epithelium in each end organ, some directional information can be gleaned and potentially used by the fish. This is still an area of much active research however and the precise mechanisms responsible for directional hearing in fish remain unclear.

\section{PHYSIOLOGY OF THE ADULT FISH EAR,}

Although there are a wide diversity of hearing mechanisms and abilities in teleosts, fish can be split into two non-taxonomic groups, hearing generalists and hearing specialists. Hearing generalists are those species which have no apparent specializations for expanded hearing. The primary path for acoustic information to reach the inner ear in generalists is via direct impingement of sound waves on the ear. Generalist 
species typically can hear frequencies of below $500 \mathrm{~Hz}$ but not much above, although some can hear up to $1000 \mathrm{~Hz}^{12}$. Hearing specialists can transfer pressure information from other structures to the inner ear (typically a gas-filled bubble either next to the ear or with a direct coupling to the ear), thus expanding the frequency range and/or sensitivity of hearing. The best known of these structures are the Weberian ossicles of ostariophysan fish, a series of bones connecting the swim bladder to the inner ear. It was thought that the highest detectable frequency of any fish was approximately $5,000 \mathrm{~Hz}$ in some ostariophysans but it has recently been shown that at least two species in the order Clupeiformes can hear up to $180,000 \mathrm{~Hz}^{13}$. Clupeiform fish all have a pair of gas-filled structures (the auditory bullae), connected to the utricular epithelium and this structure may be responsible for the enhanced hearing range of these species.

\section{MORPHOLOGICAL EAR DEVELOPMENT}

The precise timing of ear development varies between species $\left(e . g .^{14,15}\right)$ and is also affected by the conditions under which fish are reared ${ }^{16}$ but the general patterns appear similar between species. The teleost ear forms from the auditory placode which becomes a hollow vessicle, the otocyst, soon after first appearance to form the lumen of the ear ${ }^{14}$. The otocyst enlarges and protrusions develop from the walls of the lumen inward, forming four columns of tissue which eventually become the three semicircular canals $^{14,17}$. During the period of semicircular canal development otoliths and sensory hair cells also form in the otocyst. Soon after initial otolith formation, the first sensory hair cells and supporting cells appear. Hair cells are then added $^{16}$ and the otolith grows ${ }^{18}$ through the life of the fish, keeping pace with growth of the ear itself. The utricular and saccular hair cells typically form first and together, the lagenar otoliths and the lagena itself not forming until much later. An interesting question is the origin of the lagena. This end organ appears to form much later during the larval period in the species that have been examined but it remains unclear as to the source of cells of this end organ. Do they form as an outpocketing of the saccule or from a separate origin? This is a particularly interesting question for evolution since the homology of the fish lagena to the bird basilar papilla and mammalian cochlea is still an open question ${ }^{19}$. If the fish lagena is homologous to similar portions of the bird and mammalian ear then the developmental precursors should also be the same. There has as yet been no comparative study of the development of this portion of the ear across vertebrate groups but such a study would be very useful in trying to determine the evolutionary origins of the vertebrate ear.

\section{DEVELOPMENT OF AUDITORY FUNCTION}

Changes in auditory ability as fish grow are poorly understood regardless of technique used. Using physiology, fish have been found to show no difference in auditory ability with growth (Cyprinida $e^{16,20}$ ), a large improvement in auditory sensitivity with growth (Pomacentridae ${ }^{21}$ ), small improvements in sensitivity with growth over a very restricted size range (Pagridae ${ }^{22}$, Belontiida $e^{23}$ ) or no change in sensitivity but large changes in maximum detectable frequency (Cyprinidae: Higgs et al., in prep). In terms of behavior, fish generally show an increased responsiveness to acoustic stimuli [e.g. Clupeidae ${ }^{8}$, Sciaenidae ${ }^{24}$ ), although the range of frequencies used in these studies have thus far been limited. The differing results found thus far may be due to the limited species that have been studied. In ostariophysan fish, the main constraint on hearing ability may be the development of the Weberian ossicles (Higgs et al. in prep). As the ossicles develop, they may shift higher frequencies to the ear. By the size at which the fish develop an ossicular connection to the swim bladder the ear may be fully capable of detecting inputs at "adultlike" levels. The development of the ossicular connection between the swim bladder and inner ear may work in a similar way to that seen with the development of the middle ear bone(s) of birds and mammals. This would explain why the studies that have thus far been conducted on hearing development in ostariophysans ${ }^{16,20}$ have found no change in sensitivity with growth. Of the other species studied physiologically, only one study ${ }^{23}$ has examined hearing development in a nonostariophysan specialist, the gourami Trichopsis vittata. Gouramis have a small gas bubble (the suprabranchial chamber) directly connected to the ear. Developmental changes in the suprabranchial chamber might have a more immediate developmental effect on hearing abilities in this group, enhancing sensitivity of the auditory system as the chamber fills with gas. The other groups examined physiologically (Pomacentridae ${ }^{21}$ and Pagridae $^{22}$ ) have no obvious specializations for enhanced hearing so developmental tests in these animals might show more dependence on development of the ear itself rather than on other portions of the auditory system. Not until more developmental audiograms are obtained will 
we be able to determine how or why fish as a group differ in terms of developmental hearing abilities.

\section{RELEVANCE TO FISHERIES SCIENCE}

The study of the development of fish hearing is interesting in terms of sensory ecology and evolution but it is also directly relevant to scientists involved both in aquaculture systems and in fisheries management. The modern aquaculture facility is a noisy place. As detailed by Bart et $a l^{25}$ there are two peaks of noise in the typical aquaculture facility, one broad maximum under $400 \mathrm{~Hz}$ and a second higher frequency peak around $2500 \mathrm{~Hz}$. The sound levels reached across the frequency spectrum are well within the hearing ranges of many fish species ${ }^{12,25}$ and for some of the situations examined by Bart et $\mathrm{al}^{25}$ the sound levels are close to those that have been used to cause auditory hair cell damage in fish ${ }^{26}$. Fish raised in rearing facilities are often less robust than wild fish of the same species ${ }^{27}$ and the stress and damage caused by excess noise in the aquaculture facility may be one factor in this reduced viability. While it is impractical to make a commercial aquaculture facility as quiet as a more wild environment, measures such as adding insulation to the outside and supports of tanks may reduce noise ${ }^{25}$ and therefore reduce stress and enhance viability of reared fishes.

Information on all sensory capabilities, not just audition, of reared larval fish should also be considered when deciding at what stage to release larvae into the wild for restocking efforts. The decision of at what stage to stock fish into a natural setting is multifaceted and must weigh practical concerns of cost of rearing fish, timing to ensure proper release into the habitat of interest, and viability of the fish upon release. I would suggest that one of the factors weighed in the viability concerns should be sensory capabilities. A short delay in the timing of release may allow more sensory systems to become functional, therefore allowing better survival probability for the larvae. While sensory biology would never of course be the sole deciding factor in such a complex procedure as restocking wild or artificial populations, it might behoove managers to take this into consideration when designing the rearing and stocking models.

\section{ACKNOWLEDGEMENTS}

This review was greatly improved through comments of Drs. Kirsten R. Poling and Arthur N. Popper. Dr. Popper also provided lab space, financial support, and intellectual and moral support during and before the time at which the review was written. Support during the writing of this review was provided by the National Institutes of Health, National Institute of Deafness and other Communication Disorders.

\section{REFERENCES}

1. New JG, Fewkes LA, Khan AN. Strike feeding behavior in the muskellunge, Esox masquinongy: contributions of the lateral line and visual sensory systems. J. exp. Biol. 2001; 204: 1207-1221.

2. Blaxter JHS, Fuiman LA. The role of sensory systems of herring larvae in evading predatory fishes. J. mar. biol. Assoc. U.K. 1990; 70: 413-427.

3. Blaxter JHS. Development of sense organs and behaviour of teleost larvae with special reference to feeding and predator avoidance. Trans. Am. Fish. Soc. 1986; 115: 98-114.

4. Blaxter JHS. Structure and development of the lateral line. Biological Reviews 1987; 62: 471-514.

5. Fernald RD. Teleost vision: seeing while growing. J. Exp. Zool. Suppl. 1991; 5: 167-180.

6. Kotrschal $\mathrm{K}$, Adam $\mathrm{H}$, Brandstätter R, Junger $\mathrm{H}$., Zaunreiter $\mathrm{M}$, Goldschmid A. Larval size constraints determine directional ontogenetic shifts in the visual system of teleosts. Z. zool. Syst Evolut-forsch 1990; 26: 166-182.

7. Zelick R, Mann DA, Popper, A.N. Acoustic communication in fishes and frogs. In: Fay RR \& Popper AN (eds). Comparative Hearing: Fish and Amphibians. SpringerVerlag New York, 1999; pp.363-411.

8. Blaxter JHS, Batty RS. The development of startle responses in herring larvae. J. mar. biol. assoc. U.K. 1985; 65: 737750.

9. Haine OS, Toliemieri N, Mongtomery JC. Directional orientation to reef sound by pre-settlement reef fish larvae. Bioacoustics. in press

10. Popper AN, Fay RR. The auditory periphery in fishes. In: Fay RR, Popper AN (eds). Comparative Hearing: Fish and Amphibians. Springer-Verlag New York, 1999; pp.43-100.

11. Schuif A. Directional hearing of cod (Gadus morhua) under approximate free-field conditions. J Comp Physiol 1975; 98: 307-332.

12. Fay RR. Hearing in Vertebrates: a Psychophysics Databook. Hill-Fay Assoc., Winnetka IL USA. 1988.

13. Mann DA, Higgs DM, Tavolga WN, Souza MJ, \& Popper AN. Ultrasound detection by clupeiform fish. J. Acoust. Soc. Am. 2001; 109: 3048-3054.

14. Haddon C, Lewis J. Early ear development in the embryo of the zebrafish, Danio rerio. J. Comp. Neurol. 1996; 365: 113128.

15. Becerra $M$, Anadon R. Fine structure and development of ionocytes areas in the labyrinth of the trout (Salmo trutta fario). J. Anat. 1993; 183: 463-474. 
16. Higgs DM, Souza MJ, Wilkins HR, Presson J, and Popper AN. Age related changes in the inner ear and hearing ability of the adult zebrafish (Danio rerio). 2002; JARO. 3: in press

17. Waterman RE, Bell DH. Epithelial fusion during early semicircular canal formation in the embryonic zebrafish, Danio rerio. Anat. Rec. 1984; 210, 101114.

18. Hoff GR, Fuiman LA. Morphometry and composition of red drum otoliths: changes associated with temperature, somatic growth, and age. Comp. Biochem. Physiol. 1993; 106A: 209-219.

19. Fritzsch B. On the role played by ontogenetic remodeling and functional transformation in the evolution of vertebrate hearing. Brain Behav. Evol. 1997: 50:38-49.

20. Popper AN. The effects of fish size on auditory capacities of the goldfish. J. Aud. Res. 1971: XI, 239247.

21. Kenyon TN. Ontogenetic changes in the auditory sensitivity of damselfishes (pomacentridae). J. Comp. Physiol. A. 1996; 179: 553-561.

22. Iwashita $A$, Sakamoto $M$, Kojima $T$, Watanabe $Y$, Soeda H. Growth effects on the auditory threshold of Red Sea bream. Nippon Suisan Gakkaishi 1999; 65: 833-838.

23. Wysocki LE, Ladich $F$. The ontogenetic development of auditory sensitivity, vocalization and acoustic communication in the labyrinth fish Trichopsis vittata. J Comp. Physiol A 2001; 187: 177-187.

24. Fuiman LA, Smith ME, Malley VN. Ontogeny of routine swimming speed and startle responses in red drum, with a comparison of responses to acoustic and visual stimuli. J. Fish Biol. 1999; 55: 215-226.

25. Bart AN, Clark J, Young J, Zohar Y. Underwater ambient noise measurements in aquaculture systems: a survey. Aquacult. Engin. 2001; 25: 99-110.

26. Scholik AR, Yan HY. Effects of underwater noise on auditory sensitivity of a cyprinid fish. Hear. Res. 2001; 152: 17-24.

27. Blaxter JHS. Reared and wild fish-how do they compare? $10^{\text {th }}$ European Symposium on Marine Biology. 1975; 1: 11-26. 